UDC 17.022.1:37.091.3

\title{
TEACHER'S IMAGEAS A BASIS OF INCREASING COMPETITIVENESS OF HIGHER EDUCATION: A PARADIGM OF MODERN EDUCATIONAL PROCESS
}

\author{
(C) Oleksenko R.I. \\ Bogdan Khmelnytskyi Melitopol state pedagogical University (Melitopol, Ukraine) E-mail: \\ roman.xds1@ukr.net, ORCID: 0000-0002-2171-514X \\ (C) Sytnyk O.M. \\ Bogdan Khmelnytskyi Melitopol state pedagogical University (Melitopol, Ukraine) E-mail: \\ oleksander_sytnyk@i.ua ORCID: 0000-0001-7743-8148 \\ (C) Denisov I.G. \\ Bogdan Khmelnytskyi Melitopol state pedagogical University (Melitopol, Ukraine) E-mail: \\ idenisovvv@gmail.com ORCID: 0000-0003-3725-7486
}

\begin{abstract}
Abstreact. The urgency of the research topic is that the attempt, through the prism of higher education in Ukraine, is to outline the factors and opportunities for forming a positive image of a modern teacher as the basis for the competitiveness of a higher educational institution. The purpose of the article is: rethinking the teacher's image in conditions of growing demands and increasing competitiveness among higher education institutions. The objectives of the study are to summarize the data of the investigated problem and to develop a model for the development of theoretical aspects of forming a teacher's positive image in the context of the growth of the status of the university, and an analysis of the interdependence of the teacher's image and his professional competence, practical skills, and the ability to associate theory with practice. The research methodology is general scientific and special-disciplinary methods of scientific research. In particular, the methods of theoretical generalization, analogy and abstraction are used to clarify the conditions, specifics and realities of the modern educational process, in particular - in higher educational institutions; deduction and induction, analysis and synthesis - to identify systemic problems of Ukrainian universities the needs satisfaction of educational services users; the synthesis of progressive ideas on designing ways to enhance the teacher's positive image in the context of the growth of the status of higher education institutions. Also, special-disciplinary methods of scientific research are used: comparison, systematization and grouping - to generalize the model of development of theoretical aspects of creating of a positive image of the teacher in the context of the formation of the image of the university; analytical - in the analysis of the interdependence of the teacher's image and his professional competence, practical skills and ability to associate theory with practice, etc. The result of the study is a theoretical understanding of the teacher's image in the context of the formation of the competitiveness of a higher educational institution. The result of the analysis is the constant, systematic improvement of their own professional competencies. And only under this condition, the teacher will be able to rely on the authority and respect among students and colleagues. It is noted that the current state of higher education dictates the necessity of finding new ways of solving problems of increasing the efficiency of not only training, preparation of a specialist in the labor market, but also the efficiency of the activity of a higher educational establishment in conditions of autonomy. Conclusion. The positive image of the teacher, and in general the educational institution, will increase the authority of the professions and specialties of higher education. And philosophy itself should assume responsibility for the formation of the future teacher, since since ancient times, philosophy has been, is and will be the reason for the comprehension of wisdom. The image of a modern teacher largely depends on his professional competence in practical skills and the ability to instruct students to study the theory in close relationship with practice. After all, knowledge becomes effective only in the applied aspect, in particular, when applying the principle of "theory-practicetheory".
\end{abstract}

Key words: image, education, education, pedagogue, educational services.

1. Introduction. The current state of higher education dictates the need to find new ways to solve problems of increasing the effectiveness of training, training a specialist in the labor market.

Teacher's imageas a basis of increasing competitiveness of higher education: a paradigm of modern educational process 
The processes of modernization of education and the development of the educational services market present to date high demands on the teacher as a bearer of knowledge and the subject of the educational process. Professional skills alone do not ensure the successful pursuit of professional activity. It is imperative to have a permanent, systematic improvement of their own professional competencies. And only under this condition, the teacher will be able to rely on the authority and respect among students and colleagues.

\section{Analysis of literary sources and} problem statement.

Although many both domestic and foreign scientists engaged the problems of forming the image of a modern teacher and educational institution, but there are a number of unresolved issues that require urgent consideration. We would like to note the domestic scientists who are dealing with these issues, namely: V. Andrushchenko [7], I. Anosov [1], N. Boretskaya and O. Apilat [2], A. Zemlyansky [4], R. Olexenko [5; 6], P. Sauk [8], O. Sytnyk [9], O. Smilyanets [10], S. Sharov, T. Sharova [11], N. Shkvyrya [12], and others.

The current state of higher education dictates the need to find new ways to solve the problems of increasing the efficiency of not only training, training a specialist in the labor market, but also the effectiveness of the higher education institution in terms of autonomy. In this case, the role of the teacher plays an important role. Professional skills alone do not ensure the successful pursuit of professional activity. The lion's share in the choice of educational institution by students is the image of the university - the rating of the educational institution. An important part of the university's image is the image of teachers who, through their own authority and scientific status, form the image of the university.

3. Purpose and objectives. The purpose of the research is to rethink the teacher's image in conditions of growing demands and increasing competitiveness among higher education institutions. The tasks are:

- summarizing the data of the problem under investigation and improving the aspects aimed at the formulation of the hypothesis;

- substantiation of methods and principles, focused on the research;

- development of the conceptual-categorical research apparatus;

- development of a model for the development of theoretical aspects of the formation of a teacher's positive image in the context of the growth of the status of higher education institutions;

- analysis of interdependence of the teacher's image and his professional competence, practical skills and ability to associate theory with practice.

4. Research methods.Methodological basis of the article are general scientific and specialdisciplinary methods of scientific research. In particular, the methods of theoretical generalization, analogy and abstraction have been used in clarifying the conditions, specifics and realities of the modern educational process, in particular - in higher educational institutions; deduction and induction, analysis and synthesis - to identify systemic problems of Ukrainian universities in meeting the needs of educational services users; the synthesis of progressive ideas on designing ways to enhance the teacher's positive image in the context of the growth of the status of higher education institutions.

Also, special-disciplinary methods of scientific research are used: comparison, systematization and grouping - to generalize the model of development of theoretical aspects of the formation of a positive image of the teacher in the context of the formation of the image of higher educational institutions; analytical - in the analysis of the interdependence of the teacher's image and his professional competence, practical skills and ability to associate theory with practice, etc.

\section{Resultsofthestudy.}

Conceptually-categorical

research apparatus. In expanding this topic, we need to define the concept of «image», to find out the criteria for forming the teacher's image and, with it, the image of the higher educational institution.

The term «image» first appeared in 1806 in the dictionary of Noah Webster. Image (English image, from Latin imago, imitari - «simulate») artificial imitation or presentation of the external form of any object, especially the person [13].

In the modern world, a person of any profession and sphere of activity needs a sufficiently high level of education, culture and consciousness, this is especially true for those who have chosen a pedagogical sphere for their professional self-realization [6, pp. 80-83]. More and more, we have to look for opportunities and solve the modern challenges in training a modern specialist who is formed by a high school. 
In his speech to the freshmen of teachers V. Andrushchenko stressed: "You entered the pedagogical university, and therefore chose the profession the best in the state. And if the chosen profession coincides with the vocation, then the person becomes high, respectable, eternal. How many years we have not lost a destiny, we will always remember our teacher. We know: what kind of teacher is a student, a student, such a state, a state, such a nation, is a society...»[7]. It should be added that at the same time an extremely important role plays the image of the teacher.

Thanks to the law «On Higher Education» in 2014, there are great prerequisites for raising the rating and image of a higher educational institution in Ukraine. This can be achieved through the development of research centers in Ukrainian universities. So, according to the law, universities are allowed to create networks of regional research universities.

It should be emphasized that today the absolute majority of even national universities in Ukraine do not have the appropriate research support. However, its formation is without alternative. And in our interests - as soon as possible, and most importantly - more qualitatively. It is especially important that the status of national and research universities be obtained in a transparent competition, in conditions of full competition. In turn, this will create conditions for the effective and competitive development of research centers at universities.

The creation of regional research centers at universities can be achieved primarily through the formation of the appropriate material and financial base, as well as the interdisciplinary nature of the development of scientific research, the observance of modern publication requirements in international peer-reviewed and refereed publications, the creation of proper onetime specialized academic councils for the defense of dissertations, etc [9].

The teacher's image is an important subjective factor that determines the effectiveness of the entire educational work of the university. And thus, he manifests itself in everyday interaction, cooperation, communication between the teacher and students, and in organizing various types of their classroom and non-auditing activities, as well as in the style of the relationship between the teacher and the teaching staff. Given that image is an idea that a person creates himself about and serves as an external reflection of this person, as an indicator of his business and human qualities, the problem of studying the image of a teacher of higher education becomes more and more important, especially in modern conditions.

Currently, the fact that the teacher's image is capable of significantly affecting the attitude of students towards the subject of study, the department and the institution as a whole can not be doubted. In modern democratic conditions, when a student has the right to independently choose a «teacher», the teacher's image becomes of special significance. To count only on the fact that the position of a teacher of the university will completely determine its influence on students, today it is not necessary. The ability to create their own image, based on the principles of student centrist, is entirely in the hands of the teacher.

The image of the teacher and his role in the development of students' motivation have been said more and more often in recent times.New challenges and threats are coming into force, which brings time and society to the image of a «teacher-mentor», a person who shapes the future of society. A student needs a mentor and authority [11]. The more successful the student, the more he is more demanding than his mentor, therefore, it can be argued that the teacher's image plays a primary role in choosing the institution in which he plans to study.

In national societies, which are due to certain historical circumstances at the transformational level of development, educational systems play the role of the main creator of key socio-ideological, value orientations, which will later be such a society to develop [3, p. 402]. That is why it is extremely important for us to form such a model for the development of a positive image of the teacher, which would maximally contribute to the growth of the status of higher education institutions.

We would like to mention the prominent Ukrainian educators, whose works became part of the history of the formation of national pedagogy: V. Sukhomlinsky, K. Ushinsky, A. Makarenko, M. Pirogov, whose works include the idea of cardiacity (cardiocentrism). As V. Sukhomlinsky said, «I give my heart to children», this is the prototype of a modern educator, which itself will be the embodiment of professionalism, goodness, decency, justice and the same quality will be taught to its students. V. O. Sukhomlinsky literally wrote with the blood of his heart: «I can not live without children. 
Twenty years I woke up at the second and third hours of the night and I work, work, work until the morning. I look forward to the morning when the baby chirps. I never leave children, because without them I just can not live». From this quotation we imagine that an outstanding teacher appears before us in the form of a pastor who loves his parishioners, lives his life and lives for the formation of a future society.

In our opinion, one of the most important features that a modern teacher must have is love for children, love for his work. These «holy» traits will shape the image of a modern, up-todate teacher and, as a result, the image of an educational institution. In turn, the outstanding teacher K. D. Ushinsky notes «Only personality forms personality». It means that the Teacher must be educated, know his business. K. D. Ushinsky wished to see teachers well prepared for pedagogical activity. Great importance K. D. Ushinsky provided a pedagogical tact, without which any teacher «will never become a good teacher-practitioner», the teacher must love his profession, with a sense of responsibility to treat the «high vocation of the teacher», to the pedagogical affair, from which many in why the future of the people depends.

To supplement K.D. Ushinsky's pedagogical views - as a «collection of rules for education», I. P. Anosov proposes to transform it into the pedagogy of development, in particular, through the introduction of the direction of anthropological comprehension of the education of society [1, p. 227]. And this approach is actualized by A. M. Zemlyansky, emphasizing the importance of philosophical and anthropological intelligence in the field of historical existence and modern historical anthropology [4, p. 27].

It is this human-dimensional, humanitariancentered approach that can bring our high school to the level of the best European and world universities.

In our view, only philosophical approaches to the formation of a teacher of modern (wise) will give the desired result in the context of the formation of the image of himself and the higher educational institution.

The formation of the image of a teacher of higher education has always been based on the results of teaching, organizational, creative and scientific and methodological work. Modern educational institutions will be forced to undergo scientific accreditation, which will result in state funding. One of the indicators is the index: the scientific activity of a teacher, a team of scholars, a scientific publication and a scientific institution - h-index, or the index Hirsch (Hirsch).

However, it should not be limited to all kinds of biometric indicators, as there are quite a significant number of teachers among Ukrainian teachers who sometimes can not reach the proper level of these indicators even due to the difficult financial situation or problems of the technical plan. At the same time, they have a certain authority among students and colleagues at the expense of talent to conduct lectures, to develop certain methods of scientific research, etc. And why is such a positive image of the teacher can not serve as a competitive institution of higher education?

As to the economic component that affects the activities of the teacher, one can argue that fair wages will lead to educational institutions on a competitive basis, of talented teachers, committed to the cause of the creators.

In our opinion, every teacher should have the qualities of a charismatic leader. He should be, firstly, a professional of his business. Here we want to note that work for a teacher should acquire the qualities above all a hobby, while the teacher does not work, and resting. Allow him to independently determine the field of his scientific and teaching activity. Secondly, contemporary educators have such qualities as humanity, democracy in relation to students and colleagues, self-criticism, creativity and mobility. These qualities undeniably affect the image of the modern teacher. It is no secret to anyone that a modern educator suffers from significant transformations caused by the present. And as he passes this path of change, such will be the result of his becoming in the modern conditions of the globalized world.

One of the most urgent tasks of national higher education is the training of personnel able to ensure the transformation and development of all social human activities [12]. It is necessary to form a new thinking of students-specialists in conditions of variability of socio-cultural space. In view of this, intermediate tasks should also be distinguished: a) the disclosure of the experience of practical work of the modern university and the achievements of science for each specialist; b) substantiation of the necessity of continuous improvement of the methods of education of students in the real conditions of the educational process; c) activation of means of increasing the efficiency of training specialists through the revitalization and improvement of their 
educational, public-practical activities, productive labor.

All these specific tasks, scientific and methodological and educational guidelines, mechanisms for establishing the relationship between the learning process and real life, can only be carried out provided that there are highly qualified, competent, modern scientific and pedagogical staff capable of combining in the educational process substantively-professional competencies with the innovative humanistic essence of the pedagogical process.

Considering that the use of experience from partners from developed Western countries can be useful for the development of national education, it is important, in our opinion, to attract foreign specialists to teach certain disciplines, as well as regular training of Ukrainian teachers at leading European universities. "One of the important ways to improve the quality of education is to attract foreign teachers and academics from the best universities where there is a developed school of these disciplines and adapt their training programs. In addition, it is necessary to extend the practice of retraining university teachers in relevant universities of foreign countries» [2].

Such measures have a high level of efficiency in training and retraining of scientific and pedagogical staff for the system of national education, the quality of which depends on the level of consciousness and culture of the population, worldview and value orientations and professional competences. An important aspect of the problem of training and retraining of scientific and pedagogical staff for the educational system of Ukraine is a constant orientation towards a changing environment that requires a high level of scientific and theoretical and vocational-professional response, and an increase in pedagogical qualifications. "The development of the labor market, as well as the dynamics of changes on it, requires from educational institutions training and retraining of specialists with modern knowledge and skills that are fluent in theoretical knowledge bases, are known in all aspects of the practical application of innovative technologies, have the skills of renewal and improvement of knowledge during life» [10, p. 265].

Consequently, in the training and retraining of scientific and pedagogical staff for the system of modern education, we have proposed several key means of development and the principles of forming a positive teacher image, one of which is the constant improvement of his theoretical and practical experience, and to study throughout his life. At the same time, there is a need to build an extensive lifelong learning system.

«Personnel support of an innovative economy is hard to imagine without a new scientific elite, leaders in education, without creating conditions for lifelong learning. Today, throughout the world, emphasis is placed on continuing education. In most high-tech countries of the world, about $50 \%$ of adults are simultaneously studying. Therefore, one of the main resources of innovation development should be the creation of a modern mechanism for the functioning of the system of professional development and, in general, to meet the educational needs of man throughout his life» [8].

It is in our opinion that increasing our own professional and personality-moral competence through the use of life-long learning opportunities and structures is one of the most effective means for the formation and modernization of the worldview and the value orientations of Ukrainian teachers, which in turn will enhance the image of a modern educational institution [5, pp. 59-67].

The problem of educating a teacher's image and university needs a more thorough study. This is especially due to the fact that the image of a modern teacher largely depends on his professional competence, practical skills and the ability to inject students the ability to study the theory in close relationship with practice.

\section{Conclusions.}

Thus, the issues raised in the article are extremely important for the successful provision of educational services by higher educational institutions. At the same time, as a result, the teacher's image will strengthen and strengthen the competitive advantages of an educational institution. The positive image of the teacher, and in general, and the educational institution, will increase the authority of the professions and specialties of higher education. In our opinion, it is the philosophy that should take responsibility for the formation of the future teacher, since from ancient times philosophy was, is and will be the reason for the comprehension of wisdom.

It should also be concluded that the current state of higher education requires not only the development of new areas for increasing the efficiency of training and the proper training of specialists. Of particular importance is the

Teacher's imageas a basis of increasing competitiveness of higher education: a paradigm of modern educational process 
systematic improvement of their own professional competencies. After all, only under this condition, the teacher will be able to rely on the authority and respect among students and colleagues. In this case - is not the main guarantee for the growth of the teacher's image.

The image of a modern teacher largely depends on his professional competence in practical skills and the ability to instruct students to study the theory in close relationship with practice. After all, knowledge becomes effective only in the applied aspect, in particular, when applying the principle of «theory-practicetheory».

\section{Список використаних джерел}

1.Аносов І. П. Педагогічна антропологія: навч. посібник. К.: Твім інтер, 2005. 264 с.

2.Борецька Н. П. Конкурентні переваги і виклики ринкової економіки у контексті розвитку вищої освіти // Методологія досліджень та сучасні соціальні, економічні і психологічні проблеми розвитку суспільства: зб. наук. праць Донецького інституту ринку та соціальної політики. - Серія: «Економіка і менеджменТ». Донецьк: ДІР СП, 2010. С. 11-17.

3.Вища освіта та Європейський освітній простір / В. Крижко, М. Елькін, О. Старокожко, К. Тільчарова, О. Грицайова. Бердянськ, Видавець Ткачук О.В., 2015. 448 с.

4.Землянський А. М. Рецепція феноменологічних ідей у сучасній історичній антропології // VERSUS. № 1 (7). 2016. C. $26-30$.

5.Олексенко Р. Підготовка і перепідготовка кадрів у системі економічної освіти // Вища освіта України. 2013. № 2. С. 59-67.

6.Олексенко Р. Економічна освіта і виховання як засоби розвитку світоглядних засад сучасного підприємництва // Вища освіта України. 2013. № 4. С. 80-83.

7. Посвята у першокурсники-2017: [Електронний ресурс] / Прес-служба Національного педагогічного університету імені М. П. Драгоманова. - Режим доступу: http://www.npu.edu.ua/ua/podii/9ss/4310-posviata-u-pershokursnyky-2017.

8. Саух П. Ю. Якість освіти як індикатор рівня життя інформаційного суспільства // Вісник Житомирського державного університету імені Івана Франка. 2006. № 29. С. 3-7.

9.Ситник О. М. Перспективи розвитку дослідницьких центрів в українських університетах у контексті Закону «Про вищу освіту» 2014 року// Українознавчий альманах. Вип. 16. Київ, Мелітополь, 2014. C. $188-192$.

10.Смілянець О.Г.Інноваційні педагогічні технології в післядипломній освіті фахівців 3 економічної кібернетики // Сучасні інформаційні технології та інноваційні методики навчання у підготовці фахівців: методологія, теорія, досвід, проблеми: зб. наук. праць. Вінниця: Вінницький державний педагогічний університет імені Михайла Коцюбинського, 2010. Вип. 25. С. 265-272.

11. Шаров С. В., Шарова Т.М. Методологічні аспекти комп'ютерної підтримки самостійної роботи студентів-філологів: навч.-метод. посіб. [2-ге видання доп. і перероб.] [передмова проф. І. Л. Михайлина]. Харків: Федорко, 2014. 200 с.

12.Шквиря Н. О. Сутність та особливості маркетингового планування конкурентоспроможності продукції // Збірник наукових праць Таврійського державного агротехнологічного університету (економічні науки). № 3 (32), 2016. С. 164-170.

13.Webster's 1828 Dictionary: [Електронний pecypc]. - Режим доступу:https://web.archive.org/web/20070516015749/http://www.cbtministries.org/resources/webster1828.htm

\section{References}

1. Anosov, I. P. (2005). Pedahohichna antropolohiia: navch. Posibnyk. K.: Tvim inter. 264 s. [in Ukrainian].

2. Boretska, N. P. (2010). Konkurentni perevahy i vyklyky rynkovoi ekonomiky u konteksti rozvytku vyshchoi osvity // Metodolohiia doslidzhen ta suchasni sotsialni, ekonomichni i psykholohichni problemy rozvytku suspilstva: zb. nauk. prats Donetskoho instytutu rynku ta sotsialnoi polityky. - Seriia: «Ekonomika i menedzhment».Donetsk: DIR SP. P. 11-17 [in Ukrainian].

3. Vyshcha osvita ta Yevropeiskyi osvitnii prostir (2015) / V. Kryzhko, M. Elkin, O. Starokozhko, K. Tilcharova, O. Hrytsaiova. Berdiansk, Vydavets Tkachuk O.V. $448 \mathrm{~s}$.

4. Zemlianskyi, A. M. (2016). Retseptsiia fenomenolohichnykh idei u suchasnii istorychnii antropolohii // VERSUS. № 1 (7). P. 26 -30 [in Ukrainian].

5. Oleksenko, R. (2013). Pidhotovka i perepidhotovka kadriv u systemi ekonomichnoi osvity / R. Oleksenko // Vyshcha osvita Ukrainy. № 2. P. 59-67 [in Ukrainian].

6. Oleksenko, R. (2013). Ekonomichna osvita i vykhovannia yak zasoby rozvytku svitohliadnykh zasad suchasnoho pidpryiemnytstva // Vyshcha osvita Ukrainy. № 4. P. 80-83 [in Ukrainian]. 
7. Posviata u pershokursnyky-2017:[Elektronnyi resurs] / Pres-sluzhba Natsionalnoho pedahohichnoho universytetu imeni M. P. Drahomanova. - Rezhym dostupu: http://www.npu.edu.ua/ua/podii/9-ss/4310-posviatau-pershokursnyky-2017 [in Ukrainian].

8. Saukh P. Yu. (2006). Yakist osvity yak indykator rivnia zhyttia informatsiinoho suspilstva / P. Yu. Saukh // Visnyk Zhytomyrskoho derzhavnoho universytetu imeni Ivana Franka. № 29. P. 3-7 [in Ukrainian].

9. Sytnyk, O. M. (2014). Perspektyvy rozvytku doslidnytskykh tsentriv v ukrainskykh universytetakh u konteksti Zakonu «Pro vyshchu osvitu» 2014 roku // Ukrainoznavchyi almanakh. Vyp. 16. Kyiv, Melitopol, 2014. P. 188-192 [in Ukrainian].

10. Smilianets, O. H. (2010). Innovatsiini pedahohichni tekhnolohii v pisliadyplomnii osviti fakhivtsiv z ekonomichnoi kibernetyky // Suchasni informatsiini tekhnolohii ta innovatsiini metodyky navchannia u pidhotovtsi fakhivtsiv: metodolohiia, teoriia, dosvid, problemy: zb. nauk. prats. - Vinnytsia: Vinnytskyi derzhavnyi pedahohichnyi universytet imeni Mykhaila Kotsiubynskoho, 2010. Vyp. 25. P. 265-272 [in Ukrainian].

11. Sharov, S. V. (2014). Metodolohichni aspekty kompiuternoi pidtrymky samostiinoi roboty studentivfilolohiv: navch.-metod. posib. - [2-he vydannia dop. i pererob.]. Kharkiv: Fedorko. 200 s. [in Ukrainian].

12. Shkvyria, N. O. (2016). Sutnist ta osoblyvosti marketynhovoho planuvannia konkurentospromozhnosti produktsii // Zbirnyk naukovykh prats Tavriiskoho derzhavnoho ahrotekhnolohichnoho universytetu (ekonomichni nauky). № 3 (32). P. 164-170 [in Ukrainian].

13. Websters 1828 Dictionary: [Elektronnyi resurs]. - Rezhym dostupu:https://web.archive.org/web/20070516015749/http://www.cbtministries.org/resources/webster1828.htm [in Ukrainian].

Олексенко Р.И., Мелитопольский государственный педагогический университет имени Богдана Хмельницкого (Мелитополь, Украина)

E-mail: roman.xdsl@ukr.net, ORCID: 0000-0002-2171-514X

Ситник О.Н., Мелитопольский государственный педагогический университет имени Богдана Хмельницкого (Мелитополь, Украина)

E-mail: oleksander_sytnyk@i.ua, ORCID: 0000-0001-7743-8148

Денисов И.Г., Мелитопольский государственный педагогический университет имени Богдана Хмельницкого (Мелитополь, Украина)

E-mail: idenisovvv@gmail.com ORCID: 0000-0003-3725-7486

\section{ИМИДЖ ПРЕПОДАВАТЕЛЯ КАК ОСНОВА ПОВЫШЕНИЯ КОНКУРЕНТОПОСОЮБНОСТИ ВУЗА: ПАРАДИГМА СОВРЕМЕННОГО ОБРАЗОВАТЕЛЬНОГО ПРОЦЕССА}

Актуальность темы исследования в том, что предпринята попытка, сквозь призму состояния высшего образования в Украине, определить факторы и возможности формирования положительного имиджа современного преподавателя как основы конкурентоспособности высшего учебного заведения. Целью статьи является: переосмысление имиджа преподавателя в условиях роста требований и повышения конкурентоспособности среди высших учебных заведений. Целями исследования является обобщение данных исследуемой проблемы и разработка модели развития теоретических аспектов формирования положительного имиджа преподавателя в контексте роста статуса вуза, и анализ взаимозависимости имиджа преподавателя и его профессиональной компетентности, практических навыков, умения связывать теорию с практикой. Методологией исследования являются общенаучные и специально-дисциплинарные методы научного исследования. Так, в частности, методы теоретического обобщения, аналогии и абстрагирования использовано при выяснении условий, специфики и реалий современного образовательного процесса, в частности - в вузе; дедукции и индукции, анализа и синтеза для выявления системных проблем украинских вузов относительно удовлетворения потребностей потребителей образовательных услуг; синтез прогрессивных идей по проектированию путей повышения положительного имиджа преподавателя в контексте роста статуса вуза. Также использованы специальнодисциплинарные методы научного исследования: сравнение, систематизация и группировка - для обобщения модели развития теоретических аспектов формирования положительного имиджа преподавателя в контексте формирования имиджа вуза; аналитический - при анализе взаимозависимости имиджа преподавателя и его профессиональной компетентности, практических навыков и умения связывать теорию с практикой и тому подобное. Результатом исследования является теоретическое осмысление имиджа преподавателя в контексте формирования конкурентоспособности высшего учебного заведения. Результатом анализа является постоянное, системное совершенствование собственных профессиональных компетенций. И только при этом условии преподаватель сможет

Teacher's imageas a basis of increasing competitiveness of higher education: a paradigm of modern educational process 
заслуживать авторитет и уважение среди студентов и коллег. Отмечено, что современное состояние высшего образования диктует необходимость поиска новых путей решения проблем повышения эффективности не только обучения, подготовки специалиста, востребованного на рынке труда, но и эффективности деятельности высшего учебного заведения в условиях автономии. Вывод. Положительный имидж педагога, и учебного заведения, позволит повысить авторитет профессий и специальностей высшей школы. И именно философия должна взять на себя ответственность за формирование учителя будущего, ведь с древних времен философия была, есть и будет тем вожаком по постижению мудрости. Имидж современного преподавателя в значительной степени зависит от его профессиональной компетентности, практических навыков и умения прививать студентам способность изучать теорию в тесной взаимосвязи с практикой. Ведь знания становятся эффективными только в прикладном аспекте, в частности при применении принципа «теория-практика-теория».

Ключевые слова: имидж, обучение, педагог, образовательные услуги

Олексенко P.I. Мелітопольський державний педагогічний університет імені Богдана Хмельницького ( Мелітополь, Україна)

E-mail: roman.xdsl@ukr.net, ORCID: 0000-0002-2171-514X

Ситник О.М. Мелітопольський державний педагогічний університет імені Богдана Хмельницького (Мелітополь, Україна)

E-mail: oleksander_sytnyk@i.ua ORCID: 0000-0001-7743-8148

Денисов І.Г.Мелітопольський державний педагогічний університет імені Богдана Хмельницького (Мелітополь, Україна)

E-mail: idenisovvv@gmail.com ORCID: 0000-0003-3725-7486

\section{ІМІДЖ ВИКЛАДАЧА ЯК ОСНОВА ПІДВИЩЕННЯ КОНКУРЕНТОСПРОМОЖНОСТІ ВНЗ: ПАРАДИГМА СУЧАСНОГО ОСВІТНЬОГО ПРОЦЕСУ}

\section{Анотація.}

Актуальність теми дослідження в тому, що зроблена спроба, крізь призму стану вищої освіти в Україні, окреслити фактори та можливості формування позитивного іміджу сучасного викладача як основи конкурентоздатності вищого навчального закладу. Метою статті є: переосмислення іміджу викладача в умовах зростання вимог та підвищення конкурентоспроможності серед вищих навчальних закладів. Цілями дослідження є узагальнення даних досліджуваної проблеми та розробка моделі розвитку теоретичних аспектів формування позитивного іміджу викладача в контексті зростання статусу ВН3, та аналіз взаємозалежності іміджу викладача та його професійної компетентності, практичних навичок, вміння пов’язувати теорію 3 практикою. Методологія дослідження є загальнонаукові та спеціально-дисциплінарні методи наукового дослідження. Так зокрема, методи теоретичного узагальнення, аналогії та абстрагування використано при з'ясуванні умов, специфіки та реалій сучасного освітнього процесу, зокрема - у ВНЗ; дедукції та індукції, аналізу та синтезу - для виявлення системних проблем українських ВНЗ стосовно задоволення потреб споживачів освітніх послуг; синтез прогресивних ідей щодо проектування шляхів підвищення позитивного іміджу викладача в контексті зростання статусу ВНЗ. Також використано спеціально-дисциплінарні методи наукового дослідження: порівняння, систематизація та групування - для узагальнення моделі розвитку теоретичних аспектів формування позитивного іміджу викладача в контексті формування іміджу ВНЗ; аналітичний - при аналізі взаємозалежності іміджу викладача та його професійної компетентності, практичних навичок та вміння пов’язувати теорію з практикою тощо. Результатом дослідження є теоретичне осмислення іміджу викладача в контексті формування конкурентоспроможності вищого навчального закладу. Результатом аналізу є постійне, системне вдосконалення власних фахових компетенцій. І лише за цієї умови викладач зможе заслуговувати на авторитет і повагу серед студентів і колег. Відзначено, що сучасний стан вищої освіти диктує необхідність пошуку нових шляхів вирішення проблем підвищення ефективності не лише навчання, підготовки фахівця, затребуваного на ринку праці, але і ефективності діяльності вищого навчального закладу в умовах автономії. Висновок. Позитивний імідж педагога, та загалом i навчального закладу, дасть змогу підвищити авторитет професій та спеціальностей вищої школи. I саме філософія має взяти на себе відповідальність за формування вчителя майбутнього, адже з прадавніх часів філософія була, є і буде тим поводарем по осягненню мудрості. Імідж сучасного викладача значною мірою залежить від його професійної компетентності практичних навичок та вміння прививати студентам здатність вивчати теорію в тісному взаємозв'язку з практикою. Адже знання стають ефективними лише в прикладному аспекті, зокрема при застосуванні принципу «теорія-практика-теорія».

Ключові слова: імідж, навчання, освіта, педагог, освітні послуги.

Стаття рекомендована до публікациї д.філософ.н., проф. Пунченко О.П. (Одеса, Украӥна) 
Надійшла до редколегії: 15. 02.2018 р. Прийнята до друку: 20. 02.2018 р.

Олексенко P.I., Мелітопольський державний педагогічний університет імені Богдана Хмельницького ( Мелітополь, Україна), вул. Гетьманська, 20, Мелітополь, Запорізька область, 72300, Україна

E-mail: roman.xds1@ukr.net, ORCID: 0000-0002-2171-514X

Ситник О., Мелітопольський державний педагогічний університет імені Богдана Хмельницького (Мелітополь, Україна), вул. Гетьманська, 20, Мелітополь, Запорізька область, 72300, Україна

E-mail: oleksander_sytnyk@i.ua ORCID: 0000-0001-7743-8148

Денисов I., Мелітопольський державний педагогічний університет імені Богдана Хмельницького (Мелітополь, Україна), вул. Гетьманська, 20, Мелітополь, Запорізька область, 72300, Україна

E-mail: idenisovvv@gmail.com ORCID: 0000-0003-3725-7486

Teacher's imageas a basis of increasing competitiveness of higher education: a paradigm of modern educational process 